\title{
Insulin-like growth factors prevent cytokine-mediated cell death in isolated islets of Langerhans from pre-diabetic non-obese diabetic mice
}

\author{
D J Hill 1,3,4,8, J Petrik ${ }^{1,3,8}$, E Arany ${ }^{1,4}$, T J McDonald ${ }^{1,4,5,6,9}$ and \\ T L Delovitch ${ }^{2,4,7}$
}

\author{
${ }^{1}$ Lawson Research Institute, St Joseph's Health Centre, London, Ontario N6A 4V2, Canada \\ ${ }^{2}$ The Autoimmunity and Diabetes Group, The John P Robarts Research Institute, 1400 Western Road, London, Ontario N6G 2V4, Canada \\ ${ }^{3}$ Department of Physiology, University of Western Ontario, London, Ontario N6A 5A5, Canada \\ ${ }^{4}$ Department of Medicine, University of Western Ontario, London, Ontario N6A 5A5, Canada \\ ${ }^{5}$ Department of Biochemistry, University of Western Ontario, London, Ontario N6A 5A5, Canada \\ ${ }^{6}$ Department of Pharmacology and Toxicology, University of Western Ontario, London, Ontario N6A 5A5, Canada \\ ${ }^{7}$ Department of Microbiology and Immunology, University of Western Ontario, London, Ontario N6A 5A5, Canada \\ ${ }^{8}$ Department of Paediatrics, University of Western Ontario, London, Ontario N6A 5A5, Canada \\ ${ }^{9}$ London Health Sciences Centre, London, Ontario N6A 5A5, Canada \\ (Requests for offprints should be addressed to D J Hill, Lawson Research Institute, St Joseph's Health Centre, 268 Grosvenor Street, London, Ontario \\ N6A 4V2, Canada)
}

\begin{abstract}
Interleukin-1 $\beta$ (IL-1 $\beta)$, tumour necrosis factor- $\alpha$ (TNF- $\alpha)$ and interferon- $\gamma$ (IFN- $\gamma$ ) contribute to the initial stages of the autoimmune destruction of pancreatic $\beta$ cells. IL-1 $\beta$ is released by activated macrophages resident within islets, and its cytotoxic actions include a stimulation of nitric oxide (NO) production and the initiation of apoptosis. Insulin-like growth factors (IGFs)-I and -II prevent apoptosis in non-islet tissues. This study investigated whether IGFs are cytoprotective for isolated islets of Langerhans from non-obese diabetic mice (NOD) mice exposed to cytokines. Pancreatic islets isolated from 5-6week-old, pre-diabetic female NOD mice were cultured for $48 \mathrm{~h}$ before exposure to IL-1 $\beta$ ( $1 \mathrm{ng} / \mathrm{ml})$, TNF- $\alpha$ $(5 \mathrm{ng} / \mathrm{ml})$, IFN- $\gamma(5 \mathrm{ng} / \mathrm{ml})$ or IGF-I or - II $(100 \mathrm{ng} / \mathrm{ml})$ for a further $48 \mathrm{~h}$. The incidence of islet cell apoptosis was increased in the presence of each cytokine, but this was significantly reversed in the presence of IGF-I or -II (IL-1 $\beta$ control $3 \cdot 5 \pm 1 \cdot 6 \%, \quad$ IL-1 $\beta \quad 1 \mathrm{ng} / \mathrm{ml} \quad 27 \cdot 1 \pm$ $5 \cdot 8 \%$, IL-1 $\beta+$ IGF-I $100 \mathrm{ng} / \mathrm{ml} 4 \cdot 4 \pm 2 \cdot 3 \%, P<0 \cdot 05)$. The
\end{abstract}

majority of apoptotic cells demonstrated immunoreactive glucose transporter 2 (GLUT-2), suggesting that they were $\beta$ cells. Islet cell viability was also assessed by trypan blue exclusion. Results suggested that apoptosis was the predominant cause of cell death following exposure to each of the cytokines. Co-incubation with either IGF-I or -II was protective against the cytotoxic effects of IL-1 $\beta$ and TNF- $\alpha$, but less so against the effect of IFN- $\gamma$. Exposure to cytokines also reduced insulin release, and this was not reversed by incubation with IGFs. Immunohistochemistry showed that IGF-I was present in vivo in islets from pre-diabetic NOD mice which did not demonstrate insulitis, but not in islets with extensive immune infiltration. Similar results were seen for IGF-binding proteins (IGFBPs). These results suggest that IGFs protect prediabetic NOD mouse islets from the cytotoxic actions of IL-1 $\beta$, TNF- $\alpha$ and IFN- $\gamma$ by mechanisms which include a reduction in apoptosis.

Journal of Endocrinology (1999) 161, 153-165

\section{Introduction}

In humans, type 1 diabetes is associated with a $\mathrm{T}$ lymphocyte and monocytic infiltration of the pancreas leading to insulitis, and T-cells directed against intrinsic $\beta$ cell antigens have been isolated (Gepts \& Lecompte 1981, Pankewycz et al. 1995). Using rodent models of spontaneous diabetes such as the non-obese diabetic (NOD) mouse, the crucial mediatory role of T-cells has been confirmed (Castano \& Eisenbarth 1990, Elliott \& Flavell 1994). However, the major population of infiltrating immune cells during the early stages of insulitis in animal models of diabetes are macrophages, which are capable of releasing cytokines such as interleukin-1 $\beta$ (IL-1 $\beta$ ), tumour necrosis factor- $\alpha$ (TNF- $\alpha$ ) and interferon- $\gamma$ (IFN- $\gamma$ ) which can induce $\beta$ cell damage. An inhibition of the cytotoxic actions of macrophage-derived cytokines may prevent initial $\beta$ cell damage and limit autoantigen release. 
The NOD mouse is a useful model of autoimmune diabetes in which an insulitis precedes $\beta$ cell destruction in the majority of female animals, but not males. At 5-6 weeks, females show a heterogeneity of pancreatic islet morphology, with some islets demonstrating heavy infiltration of immune cells, and others being untouched.

Exposure of rat islets to exogenous IL- $1 \beta$ for $6 \mathrm{~h}$ or less induces a transient increase in glucose-stimulated insulin release, but a more prolonged exposure causes a decrease in $\beta$ cell insulin synthesis and content, a decrease in DNA synthetic rate when using neonatal islets, and cell death (Mandrup-Poulsen 1986, Comens et al. 1987, Spinas et al. 1987). Human islets may be less sensitive to the detrimental effects of IL-1 $\beta$ (Rabinovitch et al. 1990, MandrupPoulsen 1996), and the mechanisms of cell death following cytokine exposure may also involve necrosis (Delaney et al. 1996). The initiation of $\beta$ cell damage in rats by IL-1 $\beta$ requires signalling via the high affinity IL-1 receptor, mRNA transcription and de novo protein synthesis, and diminished mitochondrial function (Helqvist et al. 1989, Hammonds et al. 1990). IL-1-induced damage to $\beta$ cell function and the loss of viability are both linked to the production of free radicals such as nitric oxide $(\mathrm{NO})$, and specific inhibitors of $\mathrm{NO}$ formation will maintain $\beta$ cell viability (Stamler et al. 1992, Kaneto et al. 1995). Corbett \& McDaniel (1995) and Delaney et al. (1993) have demonstrated that an intra-islet release of IL-1 following passenger macrophage activation leads to the expression of inducible NO synthase (NOS) within the $\beta$ cells, and consequent damage. Other cytokines, such as TNF- $\alpha$ and IFN- $\gamma$ have also been shown to induce NO formation in $\beta$ cells, and in potentially adjacent cells within the islets such as macrophages, endothelial cells and fibroblasts (Amber et al. 1988, Kilbourn \& Belloni 1990). Ankarcrona et al. (1994) and Suarez-Pinzon et al. (1994) both showed that the ability of IL- $1 \beta$, TNF- $\alpha$ and IFN- $\gamma$ to induce NO synthesis causing cell death in RINm5F rat insulinoma cells involved the induction of programmed cell death, or apoptosis. Apoptosis is characterized by DNA fragmentation, leading to a typical laddering appearance, and has also been associated with an altered expression ratio of the genes $\mathrm{Bcl}-2$ and Bax (Oltvai et al. 1993).

There is considerable evidence that insulin-like growth factors (IGFs) are major contributors to $\beta$ cell growth, maturation and function, and are expressed by islet cells throughout life (Hill \& Hogg 1992). However, IGFs may also act as survival factors by limiting apoptosis in many cell types (Geier et al. 1992, Rodriguez-Tarduchy et al. 1992, D’Mello et al. 1993, Muta \& Krantz 1993, Chun et al. 1994, Harrington et al. 1994, Galli et al. 1995, Stewart \& Rotwein 1996). The mechanisms by which IGFs are able to protect cells from induced apoptosis are not known, and could be varied. However, IGF-I has been shown to inhibit the induction of NOS in some tissue types, such as vascular smooth muscle (Schini et al. 1994), and could potentially interfere with cytokine-stimulated NO synthesis.

Circumstantial evidence exists to link the IGF axis to the regulation of apoptosis in vivo within islets of Langerhans. Recently, it has been suggested that a transient wave of apoptosis is responsible for a reduction in $\beta$ cell number after 1-2 weeks of postnatal life in the rat (Scaglia et al. 1997). This would coincide temporarily with our demonstration of a falling pancreatic expression of IGF-II at this time in the rat, when pancreatic expression of IGF-I has not yet achieved adult values (Hogg et al. 1994). A hyperplasia of $\beta$ cells occurs during pregnancy in the rat as part of a progressive rise in the percent endocrine tissue in the pancreas, and in peripheral blood insulin. Following parturition, $\beta$ cell mass and insulin release quickly return to that in the non-pregnant state, and this is more rapid in lactating than in non-lactating rats (Marynissen et al. 1983). The reduction in $\beta$ cell number has been shown to result from apoptosis (Scaglia et al. 1995). Circulating levels of IGF-I are greatly elevated in the rat during pregnancy, and fall rapidly following delivery (Daughaday \& Kapadia 1978). Treatment of the pre-diabetic NOD mouse with IGF-I prevents the onset of autoimmune diabetes (Bergerot et al. 1995, Kaino et al. 1996). IGF-I is also able to reduce the incidence of diabetes following the adoptive transfer of autoreactive T-cells from diabetic to pre-diabetic mice (Bergerot et al. 1996). This was associated with a reduced insulitis, and also altered $\mathrm{T}$-cell trafficking to the spleen and thymus, which suggests a possible mechanism of action of IGF-I in lymphoid tissues in addition to direct effects on islet survival.

The purpose of the present study was to examine the ability of IGFs-I and -II to alter the survival of islets isolated from pre-diabetic NOD mice, following exposure to deleterious cytokines, and to examine the presence of IGF-I in the pancreata of such animals.

\section{Materials and Methods}

\section{Isolation of islets}

Female NOD mice of 5-6 weeks age were provided from the breeding colony at the J P Robarts Research Institute, London, Ontario, and were allowed free access to food and water. All procedures were performed with ethical approval of the Animal Care Committee of the University of Western Ontario. Pancreatic islets were isolated by a modification of the method of Lacy \& Kostianovsky (1967). Briefly, mice were anaesthetized by intraperitoneal injection of ketamine hydrochloride $(50 \mathrm{mg} / \mathrm{kg}$ ) and Rompun xylazine $(15 \mathrm{mg} / \mathrm{kg})$; the pancreas was exposed and injected at multiple sites with a total of $5 \mathrm{ml}$ sterile, ice-cold Hank's buffered salts solution, pH 7.5 (HBSS; Gibco BRL, Burlington, ON, Canada) containing 2\% (v/v) fetal calf serum (FCS; Gibco BRL). The animals 
were killed by a surgical pneumothorax and the distended pancreas was removed, finely-chopped with scissors in a Petri dish containing $20 \mathrm{ml}$ ice-cold HBSS $+2 \%$ (v/v) FCS, and the fragments transferred to glass centrifuge tubes for digestion with collagenase type V (14 mg/ pancreas; Sigma Chemical Co., St Louis, MO, USA) from Clostridium histoliticum. Collagenase was solubilized in HBSS (5 ml) and the tissue digestion performed initially for $3 \mathrm{~min}$ at $38^{\circ} \mathrm{C}$ in a shaking water bath $(200$ cycles/ $\mathrm{min}$ ), followed by $2-3 \mathrm{~min}$ at $120 \mathrm{cycles} / \mathrm{min}$. The digestion was terminated by the addition of $10 \mathrm{ml}$ ice-cold HBSS, the contents dispersed by pipette, and tissue collected by centrifugation at $1000 \mathrm{~g}$ for $10 \mathrm{~min}$. Two washes with ice-cold HBSS were performed, with collection by centrifugation at 450 and $250 \mathrm{~g}$ respectively.

Ficoll gradient centrifugation was used to separate islets of Langerhans from the digested tissue (McDaniel et al. 1984). Ficoll 400DL (Sigma) was prepared in 0.5 M Hepes buffer (Sigma) containing HBSS, $10000 \mathrm{U} / \mathrm{ml}$ penicillin and $10 \mathrm{mg} / \mathrm{ml}$ streptomycin, $\mathrm{pH} \mathrm{7 \cdot 4}$. Solutions were sterilized by autoclave prior to addition of antibiotics. Each tissue digest was dispersed within $4 \mathrm{ml} 25 \%$ (w/v) Ficoll, and $2 \mathrm{ml}$ each of 23, 20.5 and 11\% Ficoll layered sequentially above this as discontinuous gradients. The glass tubes were then centrifuged at $700 \mathrm{~g}$ for $10 \mathrm{~min}$ at $22{ }^{\circ} \mathrm{C}$, and islet tissue harvested by pipette from the $20 \cdot 5-11 \%$ Ficoll interface and placed in $10 \mathrm{ml} \mathrm{HBSS}+2 \%$ (v/v) FCS. The islets were dispersed by pipette and collected by centrifugation at $1000 \boldsymbol{g}$ for $20 \mathrm{~s}$. Islets were washed twice in fresh HBSS buffer with collection by centrifugation at 450 and $200 \mathrm{~g}$ respectively, and the final yield suspended in $15 \mathrm{ml} \mathrm{HBSS}+2 \%$ (v/v) FCS in a plastic Petri dish.

Islets were counted and harvested manually with a pipette under a dissecting microscope, and dispersed into non-tissue culture grade plastic culture dishes $(10 \mathrm{~cm}$ diameter; Falcon, Lincoln Park, NJ, USA) containing $20 \mathrm{ml}$ RPMI 1640 medium (Gibco) supplemented with $10 \%$ (v/v) FCS, $25 \mathrm{mM}$ Hepes, 2.06 M L-glutamine (Sigma), $10000 \mathrm{U} / \mathrm{ml}$ penicillin, $50 \mu \mathrm{g} / \mathrm{ml}$ streptomycin, and $11.1 \mathrm{mM}$ glucose. Islets were incubated for $48 \mathrm{~h}$ at $37{ }^{\circ} \mathrm{C}$ in a humidified atmosphere of $95 \% \mathrm{O}_{2}, 5 \% \mathrm{CO}_{2}$. A yield of islets from a single pancreas was between approximately 80 and 150, and the islets obtained from the pancreata of between four and six animals were pooled to generate sufficient islets for a single experiment.

\section{Islet culture}

For studies of apoptosis, islets were plated into eight-well chamber slides (Lab-Tek, Nalge-Nunc Int., Naperville, IL, USA) (20 islets per well) and allowed to attach to the glass slides overnight in a humidified incubator at $37^{\circ} \mathrm{C}$. Islets were plated at a density of approximately 20 islets per chamber, and the culture medium consisted of glucosefree Dulbecco's Modified Eagle Medium (DMEM; Imperial Laboratories, Andover, Hants, UK) $\mathrm{pH}$ 7·4, containing antibiotics and fungizone (as above), supplemented with $2 \mathrm{mM}$ glutamine (Gibco BRL) and $8.7 \mathrm{mM}$ glucose. Medium was further supplemented as required with recombinant human IGF-I or-II $(10-100 \mathrm{ng} / \mathrm{ml})$ (GroPep Ltd, Adelaide, SA, Australia), recombinant human IL-1 $\beta(0 \cdot 5-10 \mathrm{ng} / \mathrm{ml}), \mathrm{TNF}-\alpha(2-20 \mathrm{ng} / \mathrm{ml})$, or IFN- $\gamma \quad(1-10 \mathrm{ng} / \mathrm{ml}) \quad(\mathrm{R} \& \mathrm{D}$ Labs, Minneapolis, MN, USA), alone or in combination. Where IGF-I or -II and cytokines were present together, the IGF was added $5 \mathrm{~min}$ prior to the cytokine and allowed to equilibrate with the islets at $37^{\circ} \mathrm{C}$. After $48 \mathrm{~h}$ the culture medium was removed, and the islets washed in PBS. Islets attached during culture to chamber slides were dehydrated through ascending ethanol concentrations (50, 70, 90 and 100\%), and air-dried. Slides were stored with desiccant until histological processing.

For studies of islet viability, the islets were distributed in equal batches (50-60 islets per plate) onto non-tissue culture grade Petri dishes $(50 \mathrm{~mm}$, Falcon) containing $1 \mathrm{ml}$ tissue culture medium supplemented as described above. Islets were incubated for $48 \mathrm{~h}$. At the end of the treatment period, conditioned medium was removed following centrifugation of the contents of each culture plate at $1000 \boldsymbol{g}$ for $10 \mathrm{~min}$, and stored at $-20^{\circ} \mathrm{C}$ for subsequent analysis of insulin content. The islets were washed in phosphate-buffered saline (PBS; Gibco BRL) and assessed for viability as described below.

\section{Visualization of apoptosis}

Immunocytochemistry was performed to localize apoptotic nuclei within either tissue sections or isolated islets by molecular histochemistry (Wijsman et al. 1993) using the Apoptag in situ apoptosis detection kit (Oncor Inc., Gaithersburg, MD, USA). Islets attached during culture to chamber slides were rehydrated through descending ethanol concentrations (100, 90 and 70\%), and incubated in PBS for $5 \mathrm{~min}$. Staining was performed according to the manufacturer's protocol following incubation with proteinase K $(20 \mu \mathrm{g} / \mathrm{ml}$; Boehringer-Mannheim, Dorval, Québec, Canada) for $15 \mathrm{~min}$, washing in distilled water, and quenching of endogenous peroxidase by incubation in $2 \%(\mathrm{v} / \mathrm{v})$ hydrogen peroxide in PBS for $5 \mathrm{~min}$. Colour was generated with diaminobenzidine $(1.89 \mathrm{mM}$ activated with $0.03 \%(\mathrm{v} / \mathrm{v})$ hydrogen peroxide for $2 \mathrm{~min})$ and the tissue counterstained with methyl green or Carazzi's haematoxylin for $1 \mathrm{~min}$. Sections were dehydrated in alcohol, cleared in xylene and mounted with Permount (Eukitt, Newmarket, Ontario, Canada) under glass coverslips. Dual staining for insulin or glucose transporter 2 (GLUT-2) was performed by immunocytochemistry after detection of apoptosis and prior to counterstaining and dehydration. For the localization of insulin in islets cultured within chamber slides, a primary guinea-pig antiinsulin antibody (1:1000 dilution) (provided by Dr T J McDonald) was used with an alkaline phosphatase (blue) 
chromagen. Alkaline phosphatase substrate kit III was obtained from Vector Labs Inc., Burlingame, CA, USA. Anti-mouse alkaline phosphatase conjugate (Sigma) was applied to each section for $1 \mathrm{~h}$ at room temperature, sections washed, and alkaline phosphatase substrate applied for $20 \mathrm{~min}$. Sections were washed and counterstained with Mayer's haemalum and mounted with aqueous mounting solution. GLUT-2 was similarly localized with a rabbit anti-rat GLUT-2 antiserum (1:500 dilution) (Biogenesis Inc., Sandown, NH, USA) and an anti-rabbit alkaline phosphatase conjugate.

\section{Assessment of islet viability}

To assess islet cell viability following incubation, the islets from each plate were resuspended in $0.5 \mathrm{ml}$ PBS containing $5 \mathrm{mg} / \mathrm{ml}$ trypan blue (Sigma). Trypan blue solution was filtered through an ultramembrane $(0 \cdot 2 \mu \mathrm{m}$, Gelman Science, Ann Arbor, IL, USA) to remove particulates before use. All islets were examined immediately under a dissecting microscope and islets containing cells which had taken up trypan blue were considered non-viable. This analysis was based on a photographic assessment of at least 300 cells from each of 20 islets per variable. At the time of viability assessment, the recovery of islets was $94 \pm 3 \%$ (mean \pm s.D.) of those initially added to each culture dish, and did not differ between control cultures or those which had contained cytokines. The coefficient of variation of viability assessment for repeated measures was $4 \%$. To determine if islets were dispersed in the presence of cytokines, and therefore lost from collection and analysis, the DNA content of the recovered islets was measured. Islets were suspended in PBS $(500 \mu \mathrm{l})$ and solubilized by ultrasonication. DNA was precipitated with $1 \mathrm{ml}$ ice-cold $10 \%$ trichloroacetic acid (TCA) and solubilized by overnight incubation with $1 \mathrm{M}$ sodium hydroxide. Following neutralization with $1 \mathrm{~mol} \mathrm{HCl}$, the DNA content of islets was measured by fluorimetry using Hoechst fluorochrome 33258 (Aldrich Chemical Co., Inc., Milwaukee, WI, USA) with an excitation wavelength of $375 \mathrm{~nm}$ and an emission wavelength of $458 \mathrm{~nm}$. Calf thymus DNA $(1 \cdot 5-24 \mu \mathrm{g} / \mathrm{ml}$; Sigma) was used for calibration.

\section{Immunohistochemical localization of IGFs and IGF-binding proteins}

Male or female pre-diabetic NOD mice of 5-6 weeks of age were killed by inhalation of $\mathrm{CO}_{2}$ and the pancreas quickly removed and placed in ice-cold fixative $(0 \cdot 2 \%$ glutaraldehyde, $4 \%$ paraformaldehyde buffered with $70 \mathrm{mM}$ phosphate buffer) for $16 \mathrm{~h}$ at $4{ }^{\circ} \mathrm{C}$, followed by

Figure 1 Endocrine cell apoptosis (arrows) detected using molecular histochemistry in islets isolated from a pre-diabetic female mouse in control medium (A), after incubation with IL-1 $\beta$ $(1 \mathrm{ng} / \mathrm{ml})(B)$, or with IL-1 $\beta$ and IGF-I $(100 \mathrm{ng} / \mathrm{ml})(\mathrm{C})$.
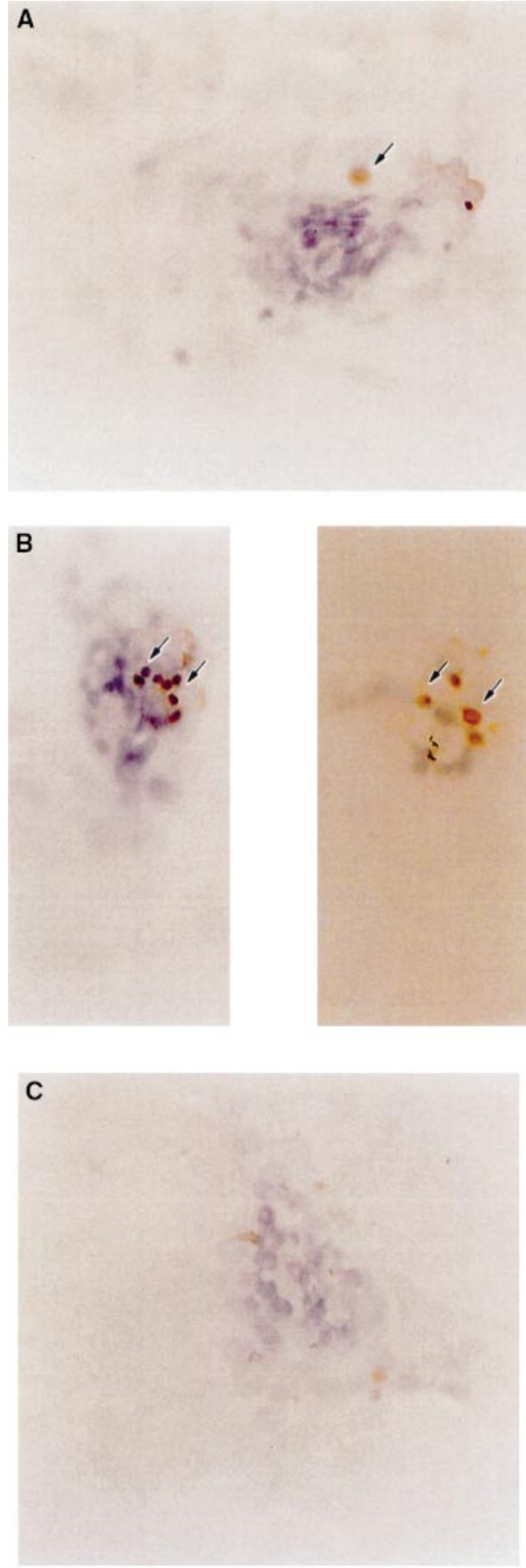
Table 1 Percentage of islets containing apoptotic nuclei (\%) in isolated pancreatic islets from NOD mice following incubation with IL- $1 \beta(1 \mathrm{ng} / \mathrm{ml})$, TNF- $\alpha(5 \mathrm{ng} / \mathrm{ml})$ or IFN- $\gamma$ $(5 \mathrm{ng} / \mathrm{ml})$, without or with IGF-I or $-\mathrm{Il}(100 \mathrm{ng} / \mathrm{ml})$. Values are means \pm S.E.M. $(n=3-4)$

\begin{tabular}{|c|c|c|c|}
\hline & Control & IGF-I & IGF-II \\
\hline Control & $3 \cdot 5 \pm 1 \cdot 6$ & $3 \cdot 1 \pm 1 \cdot 8$ & $4 \cdot 3 \pm 1 \cdot 5$ \\
\hline IL-1 $\beta$ & $27 \cdot 1 \pm 5 \cdot 8^{*}$ & $4 \cdot 4 \pm 2 \cdot 3 \dagger$ & $6 \cdot 5 \pm 2 \cdot 0$ \\
\hline Control & $5 \cdot 8 \pm 2 \cdot 1$ & $5 \cdot 0 \pm 1 \cdot 8$ & $4 \cdot 8 \pm 1 \cdot 3$ \\
\hline TNF- $\alpha$ & $54 \cdot 2 \pm 6 \cdot 9^{*}$ & $29 \cdot 3 \pm 4 \cdot 4^{*} \dagger$ & $22 \cdot 6 \pm 4 \cdot 6^{*}+$ \\
\hline Control & $6 \cdot 9 \pm 2 \cdot 6$ & $5 \cdot 7 \pm 4 \cdot 1$ & $5 \cdot 3 \pm 2 \cdot 2$ \\
\hline $\mathrm{IFN}-\gamma$ & $61 \cdot 3 \pm 4 \cdot 5^{*}$ & $43 \cdot 8 \pm 2 \cdot 5^{*} \dagger$ & $44 \cdot 3 \pm 3 \cdot 1^{*} \dagger$ \\
\hline
\end{tabular}

${ }^{*} P<0 \cdot 01$ vs no cytokine; $+P<0.05$ vs incubation with cytokine but without IGF-I or -II.

four washes at $4{ }^{\circ} \mathrm{C}$ in PBS over a $48 \mathrm{~h}$ period. Fixed tissues were dehydrated in $70 \%(\mathrm{v} / \mathrm{v})$ ethanol and embedded in paraffin. Histological sections of pancreas $(5 \mu \mathrm{m})$ were cut from paraffin blocks with a rotary microtome and mounted on Superfrost plus glass microscope slides (VWL Scientific, Mississauga, Ontario, Canada). Immunohistochemistry was performed to localize IGF-I or -II within islets by a modified avidin-biotin peroxidase method

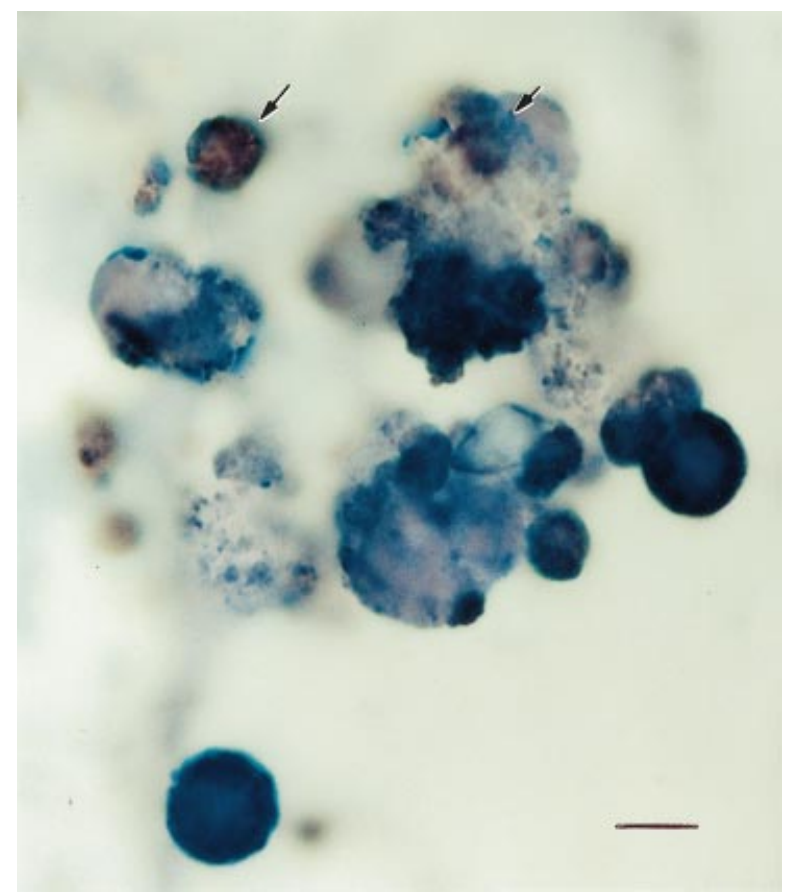

Figure 2 Endocrine cell apoptosis (arrows) detected using molecular histochemistry (brown) in islets from a pre-diabetic female mouse following tissue culture in medium containing IL-1 $\beta$. The preparations were also subjected to immunocytochemistry for GLUT-2 (blue). Islet $\beta$ cells, but not other endocrine cell types, exhibit GLUT-2 localization on the plasma membranes. The majority of condensed, apoptotic cells exhibit GLUT-2 immunoreactivity on the plasma membranes (arrows). Scale bar represents $10 \mu \mathrm{m}$.
(Hsu et al. 1981) as described by us previously (Hill \& Clemmons 1992). The primary antisera were rabbit antihuman IGF-I or -II (1:2000 dilution) (GroPep), rabbit anti-bovine IGF-binding protein-2 (IGFBP-2), rabbit anti-human IGFBP-3, or rabbit anti-human IGFBP-4 (1:1000 dilution) (UBI, Lake Placid, NY, USA). Biotinylated goat anti-rabbit IgG (Sigma) diluted 1:500 was used as a secondary antiserum. Tissue sections were counterstained with Carazzi's haematoxylin, dehydrated in an ascending ethanol series and then cleared with xylene and mounted under glass coverslips. To establish specificity of staining, the primary antisera to IGF-I or -II, or IGFBPs, were pre-absorbed overnight at $4{ }^{\circ} \mathrm{C}$ with $100 \mathrm{nM}$ homologous ligand prior to application to the sections. In each case, staining was abolished. IGF staining within islets was not abolished when the primary antisera were pre-absorbed with up to $1 \mu \mathrm{M}$ insulin. Further controls included substitution of primary antisera with non-immune serum and omission of the secondary antiserum.

\section{Insulin release}

The insulin content of conditioned culture medium was measured by radioimmunoassay (RIA) using the Wright antiserum in a modification of the method of Hales \& Randle (1963) as modified by Herbert et al. (1965), and described by us previously (Schnuerer et al. 1990). Rat insulin (Novo Nordisk, Mississauga, ON, Canada) was used for the standard curve. The within assay coefficient of variation $(\mathrm{CV})$ was $6.5 \%$ and the between assay $\mathrm{CV}$ was $9 \%$. The minimum level of detection was $2 \mathrm{fmol} / \mathrm{ml}$. There was no detectable cross-reactivity in the insulin assay with IGF-I or -II.

\section{Statistical evaluation}

Islet cultures were performed with three or four replicate culture plates or chamber slides for each variable within individual experiments derived from a pool of islets. Each experiment was repeated three to five times using pools of 
Table 2 Percentage cell viability in isolated islets from pre-diabetic female NOD mice incubated for $48 \mathrm{~h}$ with or without IL-1 $\beta(1 \mathrm{ng} / \mathrm{ml})$, TNF- $\alpha(2 \mathrm{ng} / \mathrm{ml})$, or IFN- $\gamma(5 \mathrm{ng} / \mathrm{ml})$, alone or in the presence of IGF-I or $-1 \mathrm{I}(100 \mathrm{ng} / \mathrm{ml}$. Values are means \pm S.E.M. $(n=3-4)$

\begin{tabular}{|c|c|c|c|c|}
\hline & No cytokine & IL-1及 & TNF- $\alpha$ & IFN- $\gamma$ \\
\hline Control & $90 \pm 3$ & $57 \pm 2^{* *}$ & $65 \pm 6^{*}$ & $47 \pm 6^{* *}$ \\
\hline IGF-I & $91 \pm 4$ & $87 \pm 7 \dagger$ & $80 \pm 1 \dagger$ & $58 \pm 9$ \\
\hline IGF-II & $88 \pm 3$ & $91 \pm 2 \dagger †$ & $84 \pm 2 \dagger$ & $82 \pm 3 \dagger$ \\
\hline
\end{tabular}

islets derived from separate animals. Representative experiments are shown as the mean values \pm S.E.M. Differences between mean values for variables within individual experiments were compared for statistical difference by analysis of variance. For the analysis of islet cells undergoing apoptosis when grown in chamber slides, the number of islets which contained apoptotic nuclei was considered. For histological analyses of IGF-I or -II presence, at least five separate pancreata were examined and representative views are shown.

\section{Results}

Islets isolated from pre-diabetic, female NOD mice were allowed to attach to chamber slides before exposure for $48 \mathrm{~h}$ to IL- $1 \beta(1 \mathrm{ng} / \mathrm{ml})$, TNF- $\alpha(5 \mathrm{ng} / \mathrm{ml})$ or IFN- $\gamma$ $(5 \mathrm{ng} / \mathrm{ml})$, with or without IGF-I or -II $(100 \mathrm{ng} / \mathrm{ml})$. Apoptotic nuclei were visualized using molecular histochemistry. Incubation with IL-1 $\beta$ caused an eight-fold increase in the presence of apoptotic nuclei which was significantly reduced in the presence of IGF-I (Fig. 1 and Table 1). Both TNF- $\alpha$ and IFN- $\gamma$ also caused an eightfold increase in apoptosis in islet cells, which was partly reversed by co-incubation with IGF-I or -II. These results show that cytokines induced apoptosis in islet cells, and that the incidence of apoptosis was reduced in the presence of IGFs.

Attempts to demonstrate that the islet cells undergoing apoptosis were $\beta$ cells by co-staining for insulin were unsuccessful. The compacted cells with apoptotic nuclei contained little cytoplasm and insulin immunoreactivity could not be convincingly seen. However, the central clusters of such cells within isolated islets is compatible with them once having been functional $\beta$ cells. Since $\beta$ cells preferentially express GLUT-2 on the plasma membrane, compared with other pancreatic endocrine cell types (Thorens 1992, Pang et al. 1994), we examined the presence of immunoreactive GLUT-2 on islet cells from NOD mice which were allowed to attach to chamber slides and were subsequently cultured for $48 \mathrm{~h}$ in the presence of IL-1 $\beta(2.5 \mathrm{ng} / \mathrm{ml})$ (Fig. 2). Islets were co-stained for apoptotic nuclei by molecular histochemistry. Although, under these culture conditions, islets had begun to dissociate and spread along the culture slide, clusters of cells were seen within islets which exhibited strong staining for GLUT-2, while other islet cells were immunonegative. In the presence of IL- $1 \beta$, condensed, apoptotic islet cells were seen which also contained GLUT-2 on the plasma membrane. This sometimes had an irregular distribution suggestive of blebbing of the plasma membrane, which is a feature of the apoptotic process. These results suggest that the majority of cells in which cytokine exposure induced apoptosis were $\beta$ cells.

To determine if a substantial amount of necrosis occurred in addition to apoptosis when NOD mouse islets were exposed to cytokines, a simple viability assay was used, based on trypan blue exclusion. In the presence of IL- $1 \beta$, TNF- $\alpha$ or IFN- $\gamma$, each cytokine alone caused a significant reduction in islet cell viability after $48 \mathrm{~h}$ (Table $2)$. Co-incubation with either IGF-I or -II significantly increased cell viability in the presence of IL- $1 \beta$ or TNF- $\alpha$. Co-incubation with IGF-II significantly increased viability in the presence of IFN- $\gamma$, but IGF-I did not. When islets were exposed to IL- $1 \beta(2.5 \mathrm{ng} / \mathrm{ml})$, TNF- $\alpha$ $(10 \mathrm{ng} / \mathrm{ml})$ and IFN- $\gamma(5 \mathrm{ng} / \mathrm{ml})$ in the same incubations, viability was substantially reduced (control $94 \pm 2 \%$, cytokine addition $6 \pm 2 \%$; mean \pm S.E.M., $n=4)$. Viability was significantly increased if islets were co-cultured with the three cytokines in the presence of IGF-I $(100 \mathrm{ng} / \mathrm{ml})$ $(51 \pm 8 \%, P<0 \cdot 05)$. The islet cell DNA content per culture was not altered significantly by the presence of each cytokine (control 2.61 $\pm 0.14 \mu \mathrm{g} ;$ IL-1 $\beta$ 1.98 \pm $0.35 \mu \mathrm{g} ;$ TNF- $\alpha 2.27 \pm 0.44 \mu \mathrm{g} ;$ IFN- $\gamma \quad 1.76 \pm 0.50 \mu \mathrm{g}$ $($ mean \pm s.E.M. $)$ ), suggesting that islets were not disaggregating and being lost from analysis. The release of insulin into conditioned culture medium was substantially reduced in response to each of the cytokines alone, and this was not reversed by the presence of IGF-I or -II (Table 3).

To investigate the effects of cytokine concentration on the ability of IGFs to decrease cytokine-induced cell death, islets were incubated for $48 \mathrm{~h}$ with increasing concentrations of IL- $1 \beta$, TNF- $\alpha$ or IFN- $\gamma$ with or without IGF-I $(100 \mathrm{ng} / \mathrm{ml})$. The ability of IL-1 $\beta$ to decrease islet cell viability was dose-dependent and maximally effective at a concentration of $1 \mathrm{ng} / \mathrm{ml}$ (Table 4). Co-incubation with IGF-I significantly decreased IL- $1 \beta$-induced cell death at all concentrations of cytokine tested from 0.5 to $10 \mathrm{ng} / \mathrm{ml}$. TNF- $\alpha$ was maximally effective in reducing islet cell viability at $5 \mathrm{ng} / \mathrm{ml}$ and this was significantly 
Table 3 Release of insulin ( $\mu$ Units $/ \mathrm{ml}$ ) by isolated pancreatic islets from NOD mice following exposure to IL-1 $\beta(1 \mathrm{ng} / \mathrm{ml})$, TNF- $\alpha(2 \mathrm{ng} / \mathrm{ml})$ or IFN- $\gamma(5 \mathrm{ng} / \mathrm{ml})$ with or without IGF-I or - Il $(100 \mathrm{ng} / \mathrm{ml})$. Values are means \pm S.E.M. $(n=3-4)$

\begin{tabular}{|c|c|c|c|c|}
\hline & No cytokine & IL-1及 & TNF- $\alpha$ & IFN- $\gamma$ \\
\hline Control & $212 \pm 24$ & $146 \pm 11^{*}$ & $41 \pm 9^{* *}$ & $33 \pm 5^{* *}$ \\
\hline IGF-I & $129 \pm 14 \dagger$ & $83 \pm 12$ & $42 \pm 10^{\star *}$ & $28 \pm 8^{\star \star}$ \\
\hline IGF-II & $136 \pm 9 \dagger$ & $99 \pm 24$ & $56 \pm 13^{* *}$ & $40 \pm 17^{* *}$ \\
\hline
\end{tabular}

${ }^{*} P<0 \cdot 05,{ }^{* *} P<0 \cdot 01$ vs no cytokine; $† P<0 \cdot 05$ vs incubation without IGF-I or - Il.

Table 4 Percentage cell viability in isolated islets from pre-diabetic female NOD mice incubated for $48 \mathrm{~h}$ with increasing concentrations of IL-1 $\beta$, TNF- $\alpha$, or IFN- $\gamma$, alone or in the presence of IGF-I $(100 \mathrm{ng} / \mathrm{ml})$. Values are means \pm S.E.M.. $(n=3-4)$

\begin{tabular}{|c|c|c|c|c|c|c|c|c|}
\hline & \multicolumn{8}{|c|}{ Cytokine (ng/ml) } \\
\hline & 0 & $0 \cdot 5$ & 1 & 2 & $2 \cdot 5$ & 5 & 10 & 20 \\
\hline IL-1 $\beta$ & $96 \pm 2$ & $60 \pm 2^{*}$ & $22 \pm 4^{*}$ & - & $20 \pm 2^{*}$ & - & $19 \pm 3^{*}$ & - \\
\hline IL- $1 \beta+$ IGF-I & $94 \pm 1$ & $81 \pm 3 \dagger$ & $78 \pm 4+\dagger$ & - & $66 \pm 2+\dagger$ & - & $57 \pm 7+\dagger$ & - \\
\hline TNF- $\alpha$ & $96 \pm 1$ & - & - & $76 \pm 2^{*}$ & - & $43 \pm 1^{*}$ & $40 \pm 5^{*}$ & $35 \pm 3^{*}$ \\
\hline TNF- $\alpha+$ IGF-I & $93 \pm 2$ & - & - & $81 \pm 2$ & - & $63 \pm 2 \dagger$ & $56 \pm 3 \dagger$ & $58 \pm 2 \dagger$ \\
\hline IFN- $\gamma$ & $91 \pm 3$ & - & $28 \pm 5^{*}$ & $13 \pm 2^{*}$ & - & $18 \pm 1^{*}$ & $16 \pm 4^{*}$ & - \\
\hline IFN- $\gamma+$ IGF-I & $88 \pm 6$ & - & $33 \pm 6$ & $31 \pm 3 \dagger$ & - & $28 \pm 3 \dagger$ & $15 \pm 4$ & - \\
\hline
\end{tabular}

${ }^{*} P<0.05$ vs no cytokine; $\uparrow P<0 \cdot 05, \uparrow+P<0.005$ vs incubation without IGF-I.

Table 5 Percentage cell viability in isolated islets from pre-diabetic female NOD mice incubated for $48 \mathrm{~h}$ with IL-1 $\beta(10 \mathrm{ng} / \mathrm{ml})$ with or without increasing concentrations of IGF-I. Values are means \pm S.E.M.. $(n=3-4)$

\begin{tabular}{|c|c|c|c|c|c|}
\hline & IGF-I (ng & & & & \\
\hline & 0 & 10 & 25 & 50 & 100 \\
\hline No cytokine & $92 \pm 3$ & $86 \pm 5$ & $89 \pm 2$ & $85 \pm 7$ & $87 \pm 3$ \\
\hline IL-1 $\beta$ & $23 \pm 3 \dagger$ & $36 \pm 4 \dagger$ & $42 \pm 2 \dagger$ & $55 \pm 3$ & $65 \pm 5$ \\
\hline
\end{tabular}

$† P<0 \cdot 05$ vs no cytokine.

reversed by co-incubation with IGF-I together with 5-20 ng/ml TNF- $\alpha$ (Table 4). IFN- $\gamma$ was already maximally effective at inducing islet cell death at the lowest concentration examined, $1 \mathrm{ng} / \mathrm{ml}$. A modest cytoprotective action of IGF-I was seen but was limited to concentrations of 2 and $5 \mathrm{ng} / \mathrm{ml}$ IFN- $\gamma$, and was absent at $10 \mathrm{ng} / \mathrm{ml}$ (Table 4). Since the cytoprotective effects of IGF-I were most apparent in the presence of IL-1 $\beta$, this cytokine was used to investigate the dose-dependency of IGF-I. A maximally-effective concentration of IL-1 $\beta$ was utilized, $10 \mathrm{ng} / \mathrm{ml}$, co-incubated with decreasing concentrations of IGF-I from 100 to $10 \mathrm{ng} / \mathrm{ml}$. The ability of IGF-I to decrease IL-1 $\beta$-induced cell death was clearly dose-related, with only slight protection present at $10 \mathrm{ng} / \mathrm{ml}$ but a $70 \%$ reversal of IL- $1 \beta$ action at $100 \mathrm{ng} / \mathrm{ml}$ (Table 5).

To establish that apoptosis was also a feature of islet cell death in the pre-diabetic NOD mouse pancreas in vivo, sections of pancreas from female animals of 5-6 weeks age were subjected to TUNEL immunohistochemistry. Insulitis was evident in approximately $40 \%$ of islets. In islets without immune cell infiltration, apoptotic nuclei were rare (Fig. 3A). Isolated apoptotic nuclei could be seen in islets with no evidence of insulitis (Fig. 3B), and were often seen in islets with heavy immune cell infiltration (Fig. 3D). While some apoptotic bodies may have been $\mathrm{T}$-cells or macrophages, others were clearly located in the endocrine cell populations at the centre of islets. In a minority of islets, extensive apoptosis was seen with only limited insulitis (Fig. 3C). We examined the presence of both IGFs-I and -II in pancreata from pre-diabetic, female NOD mice and from male mice. In islets from females with no or little evidence of immune infiltration, most endocrine cells showed specific staining for IGF-I (Fig. 4A), but not for IGF-II. Within the same pancreata, islets with heavy immune infiltration showed negligible staining 

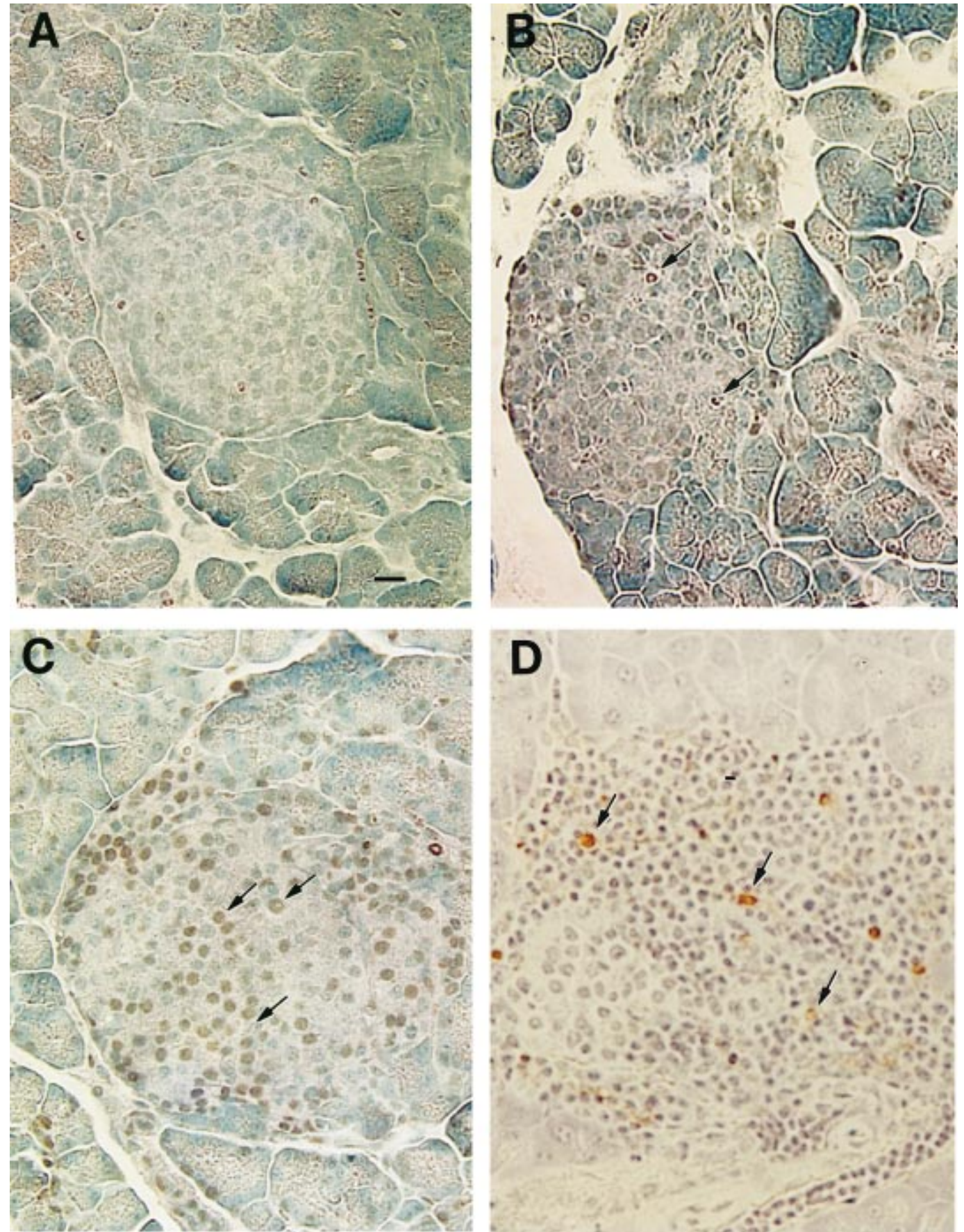

Figure 3 Molecular histochemical localization of cell apoptosis (arrows) in islets from a pre- diabetic female NOD mouse. Islets are shown without insulitis and no evidence of apoptosis (A), no insulitis and isolated apoptotic nuclei (B), peripheral insulitis, and multiple apoptosing cells (C), or heavy insulitis engulfing the endocrine cells (D). During heavy insulitis, apoptotic cells with large nuclei characteristic of the endocrine cells are surrounded by infiltrating immune cells. Scale bar represents $10 \mu \mathrm{m}$.

for either IGF-I or -II (Fig. 4B). Little IGF immunoreactivity was present in the acinar cell population. Pancreata from male NOD mice of the same age showed no evidence of immune cell infiltration of islets, and all islets were immunopositive for IGF-I. To determine whether the IGF-I immunoreactivity seen in 

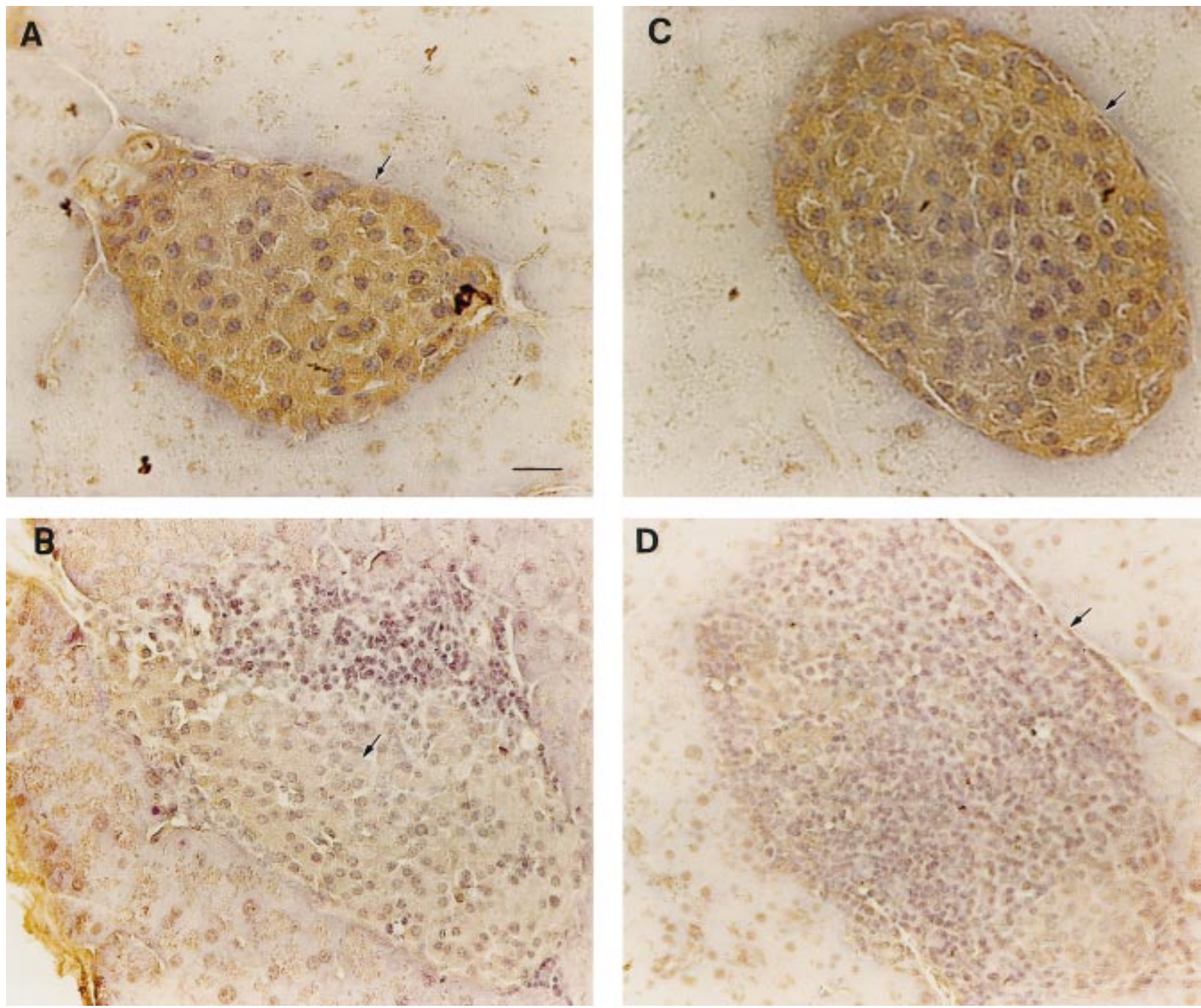

Figure 4 Immunohistochemical localization of IGF-I (A and B), or IGFBP-2 (C and D) in pancreatic islets (arrow) of pre-diabetic female NOD mice without insulitis (A and C), and in islets of the same pancreas demonstrating insulitis (B and D). Immunoreactivity for both IGF-I and IGFBP-2 is diminished during insulitis. Scale bar represents $10 \mu \mathrm{m}$.

non-infiltrated islets was due to an association with IGFBPs, immunohistochemistry was performed for IGFBPs-2, -3 and -4 . Immunoreactivity for IGFBP-2 was seen in islets not undergoing obvious infiltration (Fig. 4C), but was absent from islets with heavy immune infiltration (Fig. 4D). Similar findings were seen for the distribution of IGFBPs-3 and -4 (not shown). The co-distribution of IGF-I with IGFBPs suggests that they exist in complex on or in islet cells.

\section{Discussion}

The autoimmune process in the NOD mouse is known to involve cytokine-mediated destruction of the pancreatic $\beta$ cells in a process analogous to that seen in human type 1 diabetes (Castano \& Eisenbarth 1990). The ability of cytokines such as IL-1 $\beta$, TNF- $\alpha$ and IFN- $\gamma$ to induce $\beta$ cell death is known to be at least partly mediated by the induction of apoptosis (Delaney et al. 1993). This may involve the up-regulation of iNOS and increased intracellular levels of NO (Corbett \& McDaniel 1995), although other mechanisms may also operate including the generation of oxygen free radicals and a Fas-dependent pathway (Rabinovitch et al. 1992, Yamada et al. 1996). The present experiments show that an induction of apoptosis is a major contributor to cytokine-induced cell death in isolated islets from pre-diabetic NOD mice, and that IGFs-I and -II, which have been shown previously to limit induced apoptosis in a variety of cell types (Geier et al. 1992, Muta \& Krantz 1993, Chun et al. 1994), will also protect such islets against cytokine-mediated cell 
death, at least partly by reducing cytokine-induced apoptosis. IGF-I may also limit apoptosis by suppression of an IL-1 $\beta$-converting enzyme (Jung et al. 1996). The cells which underwent apoptosis in isolated islets exposed to cytokines demonstrated immunoreactive GLUT-2, a marker of $\beta$ cells (Thorens 1992, Pang et al. 1994), although immunoreactive insulin was no longer detectable in such compacted cells with little cytoplasm. This may reflect the terminal nature of the detection system for apoptosis used: the breakage of DNA, which occurs after considerable cell compaction and autolysis has taken place. IGF-I has recently been shown to limit IL- $1 \beta$-induced apoptosis in adult rat islets of Langerhans by a mechanism which involved a suppression of iNOS (Mabley et al. 1997). Our study extends these observations to other cytokines, and to islets during the process of autoimmune diabetes.

Some islets did not show evidence of cell death or apoptosis in response to cytokines at the doses and incubation time used. This may reflect the heterogeneous nature of the islets obtained from the pre-diabetic NOD mice, where some will already have evidence of insulitis in vivo. Those islets may well retain macrophages and/or $\mathrm{T}$-cells once isolated, although the high viability of islets in control cultures suggests that these did not exert a noticeable cytotoxic effect. However, they may represent the islets that have the greatest sensitivity to exogenous cytokines in vitro. The sensitivity of islets from the NOD mouse to exogenous cytokines was broadly similar to that reported by us recently for isolated islets from weanling rats (Petrik et al. 1998).

IGF-I $(100 \mathrm{ng} / \mathrm{ml})$ was able to significantly increase islet cell survival in the presence of up to $10 \mathrm{ng} / \mathrm{ml} \mathrm{IL}-1 \beta$, or $20 \mathrm{ng} / \mathrm{ml} \mathrm{TNF}-\alpha$. It was less effective in preventing $\beta$ cell death in response to IFN- $\gamma$, with partial protection being seen at concentrations of 2 and $5 \mathrm{ng} / \mathrm{ml}$ cytokine only. This may reflect differences in the mechanisms of IFN- $\gamma$-induced cell death compared with the other cytokines. For instance, IFN- $\gamma$ induces the increased expression of IFN-regulatory factor- 1 in pancreatic $\beta$ cells, leading to a greater increase in iNOS mRNA than achieved with other cytokines alone (Flodstrom \& Eizirik 1997). IFN- $\gamma$ is able to induce cell death in the INS-1 $\beta$ cell line independently of NO production (Laffranchi \& Spinas 1997), and this may be mediated by the induction of Fas (Yamada et al. 1996). However, in our studies, IGF-I was able to significantly reduce the rapid loss of islet cell viability seen when all three cytokines were present together. The cytoprotective effects of IGF-I in the presence of IL-1 $\beta$ were dose-related between 10 and $100 \mathrm{ng} / \mathrm{ml}$, and did not reach a maximum. It is possible that greater concentrations of IGF-I would induce increased cell viability. Exposure of pre-diabetic NOD islets to cytokines also caused a rapid decrease in insulin release, and this was not reversed by incubation with IGFs. Rather, incubation with IGFs tended to further decrease insulin release. Our estimation of insulin release will include that released from apoptosing cells, so that the direct inhibitory effects of cytokines on insulin release are probably under-estimated. These findings differ from those reported for rat islets, where IGF-I was able to reverse the inhibitory effects of IL-1 $\beta$ on insulin release (Mabley et al. 1997). Both IGFs-I and -II have previously been reported to inhibit the release of insulin from isolated adult rat islets when continuously present (Van Schravendijk et al. 1990, Hill et al. 1997, Petrik et al. 1998) in line with our findings in the NOD mouse. Other growth factors have also been found to promote the survival of $\beta$ cells following exposure to proinflammatory cytokines. Transforming growth factor $\beta$ was able to reverse the effects of IL-1 $\beta$ on insulin secretion and NO formation in rat islets and RINm5F cells (Cunningham \& Green 1994, Cunningham et al. 1994).

The pancreata of juvenile and adult rodents express IGF-I, both in the islets of Langerhans and in the ductal epithelial cells (Romanus et al. 1985, Swenne \& Hill 1989, Hogg et al. 1993, 1994). In postnatal rat islets, the source of IGF-I may primarily be glucagon cells (Maake \& Reinecke 1993). IGF-I inhibits pro-glucagon gene expression and glucagon release from an $\alpha$ cell line (Fehmann et al. 1996). All endocrine pancreas cell types express both types-1 and -2 IGF receptors (Van Schravendijk et al. 1987, Fehmann et al. 1996). However, it is not known if IGF-I is present in the pancreas of the pre-diabetic NOD mouse. Using immunohistochemistry, we found that IGF-I was associated with most cells within islets without insulitis, but that immune infiltration was associated with a loss of IGF-I immunoreactivity within the same pancreas. Little IGF-I was associated with exocrine tissues. The widespread distribution of IGF-I throughout the cells of some islets may reflect sequestration to IGFBPs which are known to be expressed within the rodent pancreas (Hill \& Hogg 1992, Hogg et al. 1994), and may not necessarily indicate de novo synthesis. This was supported by the co-localization in islets of IGF-I and IGFBPs-2, -3 and -4 , all of which showed a much reduced immunoreactivity in islets undergoing insulitis. Cytokines known to be involved in the early stages of pancreatic $\beta$ cell destruction may inhibit either the local expression or action of IGF-I or -II, or alter IGFBP release, in non-islet tissues. Both TNF- $\alpha$ and IFN- $\gamma$ were found to inhibit IGF-II gene expression in human fetal adrenal cell cultures (Ilvesmaki et al. 1993), while the latter decreased both DNA synthetic rate and IGF-II expression in human neuroblastoma cells (Martin et al. 1993). IL-1 $\beta$ and TNF- $\alpha$ were both shown to reduce IGF-I expression by rat Leydig cells (Lin et al. 1992, 1994). IGF-I is also expressed by macrophages, but this is suppressed by IFN $-\gamma$ (Arkins et al. 1995) but not by TNF- $\alpha$ (Noble et al. 1993). The loss of IGF-I immunoreactivity in islets undergoing insulitis may also reflect the presence of proteases which can selectively modify IGFBPs, and reduce their affinity 
for the ligands (McCusker \& Clemmons 1992). Exposure of rodent islets to exogenous IL-1 $\beta$ causes an increased activation of proteases, while the short-term effects of IL- $\beta$, such as decreased insulin release, could be reversed in the presence of serine protease inhibitors (Eizirik et al. 1991, Welsh et al. 1991). In summary, these experiments show that exogenous IGFs-I and -II are able to improve islet cell viability in isolated islets from the pre-diabetic NOD mouse following exposure to proinflammatory cytokines, by a process that includes suppression of apoptosis. This suggests new strategies for the use of naturally occurring growth factors to retard islet cell destruction in type 1 diabetes.

\section{Acknowledgements}

We are grateful to the Juvenile Diabetes Foundation, the Canadian Diabetes Association and the Medical Research Council of Canada for financial support to D J Hill and T L Delovitch.

\section{References}

Amber IJ, Hibbs Jr JB, Taintor RR \& Vavrin Z 1988 Cytokines induce an L-arginine-dependent effector system in non-macrophage cells. Journal of Leukocyte Biology 44 58-65.

Ankarcrona M, Dypbukt JM, Brune B \& Nicotera P 1994 Interleukin-1 beta-induced nitric oxide production activates apoptosis in pancreatic RINm5F cells. Experimental Cell Research 213 172-177.

Arkins S, Rebeiz N, Brunkereese DL, Biragyn A \& Kelley KW 1995 Interferon-gamma inhibits macrophage insulin-like growth factor-I synthesis at the transcriptional level. Molecular Endocrinology 9 350-360.

Bergerot I, Fabien N, Maguer V \& Thivolet C 1995 Insulin-like growth factor-I (IGF-I) protects NOD mice from insulitis and diabetes. Clinical and Experimental Immunology 102 335-340.

Bergerot I, Fabien N \& Thivolet C 1996 Effects of insulin-like growth factor-I and insulin on effector $\mathrm{T}$ cells generating autoimmune diabetes. Diabetes and Metabolism 22 235-239.

Castano L \& Eisenbarth GS 1990 Type 1 diabetes: a chronic autoimmune disease of human, mouse and rat. Annual Reviews of Immunology 8 647-679.

Chun SY, Billig H, Tilly JL, Furuta I, Tsafriri A \& Hsueh AJW 1994 Gonadotropin suppression of apoptosis in cultured preovulatory follicles: mediatory role of endogenous insulin-like growth factor I. Endocrinology 135 1845-1853.

Comens PG, Wolf BA, Unanue ER, Lacy PE \& McDaniel ML 1987 Interleukin 1 is potent modulator of insulin secretion from isolated rat islets of Langerhans. Diabetes 36 963-970.

Corbett JA \& McDaniel ML 1995 Intra-islet release of interleukin-1 inhibits $\beta$ cell function by inducing $\beta$ cell expression of inducible nitric oxide synthase. Journal of Experimental Medicine 181 559-568.

Cunningham JM \& Green IC 1994 Cytokines, nitric oxide and insulin secreting cells. Growth Regulation 4 173-180.

Cunningham JM, Mabley JG, Mwebe B, Kovani E \& Green IC 1994 Suppression of interleukin- $1 \beta$-induced nitric oxide synthase activity by transforming growth factor- $\beta$ in the insulin-secreting cell line RINm5F. Journal of Endocrinology 140 (Suppl) P37.

Daughaday WH \& Kapadia M 1978 Maintenance of serum somatomedin activity in hypophysectomized pregnant rats. Endocrinology 102 1317-1320.
Delaney CA, Green MHL, Lowe JE \& Green IC 1993 Endogenous nitric oxide induced by interleukin $-1 \beta$ in rat islets of Langerhans and HIT-T15 cells causes significant DNA damage as measured by the 'comet' assay. FEBS Letters 333 291-295.

Delaney CA, Tyrberg B, Bouwens L, Vaghef H, Hellman B \& Eizirik DL 1996 Sensitivity of human pancreatic islets to peroxynitriteinduced cell dysfunction and death. FEBS Letters 394 300-306.

D'Mello SR, Galli C, Ciotti T \& Calissano P 1993 Induction of apoptosis in cerebellar granule neurons by low potassium: inhibition of death by insulin-like growth factor-I and cAMP. Proceedings of the National Academy of Sciences of the USA 90 10989-10993.

Eizirik DL, Bendtzen K \& Sandler S 1991 Short exposure of rat pancreatic islets to interleukin-1 beta induces a sustained but reversible impairment in beta cell function: influence of protease activation, gene transcription, and protein synthesis. Endocrinology 128 1611-1616.

Elliott EA \& Flavell RA 1994 Transgenic mice expressing constitutive levels in islet $\beta$ cells develop diabetes. International Immunology 6 1629-1637.

Fehmann HC, Jehle P, Markus U \& Goke B 1996 Functional active receptors for insulin-like growth factors-I (IGF-I) and IGF-II on insulin-, glucagon-, and somatostatin-producing cells. Metabolism $\mathbf{4 5}$ 759-766.

Flodstrom M \& Eizirik DL 1997 Interferon- $\boldsymbol{\gamma}$-induced interferon regulatory factor-1 (IRF-1) expression in rodent and human islet cells precedes nitric oxide production. Endocrinology 138 2747-2753.

Galli C, Meucci O, Scorziello A, Werge TM, Calissano P \& Schettini G 1995 Apoptosis in cerebellar granule cells is blocked by high $\mathrm{KCl}$, forskolin, and IGF-I through distinct mechanisms of action: the involvement of intracellular calcium and RNA synthesis. Journal of Neuroscience 15 1172-1179.

Geier A, Haimshon M, Beery R \& Lunenfeld B 1992 Insulin-like growth factor-I inhibits cell death induced by cycloheximide in MCF-7 cells - a model system for analyzing control of cell death. In Vitro Cellular and Developmental Biology 28A 725-729.

Gepts W \& Lecompte PM 1981 The pancreatic islets in diabetes. American Journal of Medicine 70 105-115.

Hales CN \& Randle PJ 1963 Immunoassay of insulin with insulin antibody precipitate. Biochemical Journal 88 137-146.

Hammonds P, Beggs M, Beresford G, Espinol J, Clarke J \& Mertz RJ 1990 Insulin-secreting $\beta$ cells possess specific receptors for interleukin-1 $\beta$. FEBS Letters 261 97-100.

Harrington EA, Bennett MR, Fanidi A \& Evan GI 1994 C-myc induced apoptosis in fibroblasts is inhibited by specific cytokines. EMBO Journal 13 3286-3295.

Helqvist S, Hansen BS, Johanneson J, Anderson HU, Nielsen JH \& Nerup J 1989 Interleukin 1 induces new protein formation in isolated rat islets of Langerhans. Acta Endocrinologica 121 136-140.

Herbert V, Lau K, Gottlieb CW \& Bleicher SJ 1965 Coated charcoal immunoassay of insulin. Journal of Clinical Endocrinology 25 1375-1384.

Hill DJ \& Clemmons DR 1992 Similar distribution of insulin-like growth factor-binding proteins $-1,-2$ and -3 in human fetal tissues. Growth Factors 6 315-326.

Hill DJ \& Hogg J 1992 Expression of insulin-like growth factors (IGFs) and their binding proteins (IGFBPs) during pancreatic development in rat, and modulation of IGF actions on rat islet DNA synthesis by IGFBPs. In Pancreatic Islet Cell Regeneration and Growth, pp 113-120. Ed A Vinik. New York: Plenum.

Hill DJ, Sedran RJ, Brenner SL \& McDonald TJ 1997 Insulin-like growth factor-I (IGF-I) has a dual effect on insulin release from isolated, perifused adult rat islets of Langerhans. Journal of Endocrinology 153 15-25.

Hogg J, Han VKM, Clemmons DR \& Hill DJ 1993 Interactions of glucose, insulin-like growth factors (IGFs) and IGF binding proteins in the regulation of DNA synthesis by isolated fetal rat islets of Langerhans. Journal of Endocrinology 138 401-412. 
Hogg J, Hill DJ \& Han VKM 1994 The ontogeny of insulin-like growth factor (IGF) and IGF binding protein gene expression in the rat pancreas. Journal of Molecular Endocrinology 13 49-58.

Hsu SM, Raine L \& Fanger H 1981 Use of avidin-biotin peroxidase complex $(\mathrm{ABC})$ in immunoperoxidase techniques: a comparison between $\mathrm{ABC}$ and unlabelled antibody (PAP) procedures. Journal of Histochemistry and Cytochemistry 29 577-580.

Ilvesmaki V, Jaattela M, Saksela E \& Voutilainen R 1993 Tumor necrosis factor-alpha and interferon-gamma inhibit insulin-like growth factor-II gene expression in human fetal adrenal cell cultures. Molecular and Cellular Endocrinology 91 59-65.

Jung Y, Miura M \& Yuan J 1996 Suppression of IL-1 beta converting enzyme-mediated cell death by insulin-like growth factor. Journal of Biological Chemistry 271 5112-5117.

Kaino Y, Hirai H, Ito T \& Kida K 1996 Insulin-like growth factor I (IGF-I) delays the onset of diabetes in non-obese diabetic (NOD) mice. Diabetes Research and Clinical Practice 34 7-11.

Kaneto H, Fujii J, Seo HG, Suzuki K, Matsuoka T, Nakamura M, Tatsumi H, Yamasaki Y, Kamada T \& Taniguchi N 1995 Apoptotic cell death triggered by nitric oxide in pancreatic cells. Diabetes 44 733-738.

Kilbourn RG \& Belloni P 1990 Endothelial cell production of nitrogen oxides in response to interferon gamma in combination with tumor necrosis factor, interleukin-1 and endotoxin. Journal of the National Cancer Institute 82 772-776.

Lacy P \& Kostianovsky M 1967 Method for isolation of intact islets of Langerhans from the rat pancreas. Diabetes 34 35-39.

Laffranchi R \& Spinas GA 1997 Interferon-gamma inhibits insulin release and induces cell death in the pancreatic beta-cell line INS-1 independently of nitric oxide production. Experimental Cell Research 237 217-222.

Lin T, Wang DL, Nagpal ML, Chang WW \& Calkins JH 1992 Down-regulation of Leydig cell insulin-like growth factor-I expression by interleukin-1. Endocrinology 130 1217-1224.

Lin T, Wang DL, Nagpal ML \& Cahang W 1994 Recombinant murine tumor necrosis factor-alpha inhibits cholesterol side-chain cleavage cytochrome P450 and insulin-like growth factor-I gene expression in rat Leydig cells. Molecular and Cellular Endocrinology 101 111-119.

Maake C \& Reinecke M 1993 Immunohistochemical localization of insulin-like growth factor I and II in the endocrine pancreas of rat, dog, and man, and their coexistence with classical islet hormones. Cell and Tissue Research 273 249-259.

Mabley JG, Belin V, John N \& Green IC 1997 Insulin-like growth factor I reverses interleukin-1 beta inhibition of insulin secretion, induction of nitric oxide synthase and cytokine-mediated apoptosis in rat islets of Langerhans. FEBS Letters 417 235-238.

McCusker RH \& Clemmons DR 1992 The insulin-like growth factor binding proteins: structure and biological functions. In The Insulin-Like Growth Factors, Structure and Biological Functions, pp 110-150. Ed PN Schofield. Oxford: Oxford University Press.

McDaniel ML, Colca JR \& Kitagal M 1984 Islet cell isolation and characterization. In Methods in Diabetes Research, Vol. 1 Laboratory Methods, pp 153-166. Eds J Larner \& S Pohl. New York: John Wiley.

Mandrup-Poulsen T 1996 The role of interleukin-1 in the pathogenesis of IDDM. Diabetologia 39 1005-1029.

Martin DM, Carlson R \& Feldman EL 1993 Interferon-gamma inhibits DNA synthesis and insulin-like growth factor-II expression in human neuroblastoma cells. Journal of Neuroscience Research 34 489-501.

Marynissen G, Aerts L \& Van Assche FA 1983 The endocrine pancreas during pregnancy and lactation in the rat. Journal of Developmental Physiology 5 373-381.

Muta K \& Krantz S 1993 Apoptosis of human erythroid colonyforming cells is decreased by stem cell factor and insulin-like growth factor I as well as erythropoietin. Journal of Cellular Physiology 156 264-271.
Noble PW, Lake FR, Henson PM \& Riches DWH 1993 Hyaluronate activation of CD44 induces insulin-like growth factor-I expression by a tumor necrosis factor-alpha-dependent mechanism in murine macrophages. Journal of Clinical Investigation 91 2368-2377.

Oltvai ZN, Milliman CL \& Korsemeyer SJ 1993 Bcl-2 heterodimerizes in vivo with a conserved homolog, Bax, that accelerates programmed cell death. Cell 74 609-619.

Pang K, Mukonoweshuro C \& Wong GG 1994 Beta cells arise from glucose transporter type 2 (Glut2)-expressing epithelial cells of the developing rat pancreas. Proceedings of the National Academy of Sciences of the USA 91 9559-9563.

Pankewycz OG, Guan J-X \& Benedict JF 1995 Cytokines as mediators of autoimmune diabetes and diabetic complications. Endocrine Reviews 16 164-176.

Petrik J, Arany E, McDonald TJ \& Hill DJ 1998 Apoptosis in the pancreatic islet cells of the neonatal rat is associated with a reduced expression of insulin-like growth factor II that may act as a survival factor. Endocrinology 139 2994-3004.

Rabinovitch A, Sumoski W, Rajotte RV \& Warnock GL 1990 Cytotoxic effects of cytokines on human pancreatic islet cells in monolayer cultures. Journal of Clinical Endocrinology and Metabolism 71 152-156.

Rabinovitch A, Suarez WL, Thomas PD, Strynadka K \& Simpson I 1992 Cytotoxic effects of cytokines on rat islets: evidence for involvement of free radicals and lipid peroxidation. Diabetologia 35 409-413.

Rodriguez-Tarduchy G, Collins MKL, Garcia I \& Lopez-Rivas A 1992 Insulin-like growth factor-I inhibits apoptosis in IL-3dependent hemopoietic cells. Journal of Immunology 149 535-540.

Romanus JA, Rabinovitch A \& Rechler MM 1985 Neonatal rat islet cell cultures synthesize insulin-like growth factor I. Diabetes 34 696-702.

Scaglia L, Smith FE \& Bonner-Weir S 1995 Apoptosis contributes to the involution of beta cell mass in the postpartum rat pancreas. Endocrinology 136 5461-5468.

Scaglia L, Cahill CJ, Finegood DT \& Bonner-Weir S 1997 Apoptosis participates in the remodeling of the endocrine pancreas in the neonatal rat. Endocrinology 138 1736-1741.

Schini VB, Catovsky S, Schray-Utz B, Busse R \& Vanhoutte PM 1994 Insulin-like growth factor I inhibits induction of nitric oxide synthase in vascular smooth muscle cells. Circulation Research $\mathbf{7 4}$ $24-32$.

Schnuerer EM, Rökaeus Å, Carlquist M, Bergman T, Dupré J \& McDonald TJ 1990 Rat and porcine galanin are equipotent in inhibiting insulin responses to glucose in the anesthetized rat. Pancreas 5 70-74.

Spinas GA, Hansen BS, Linde S, Kastern W, Molvig J, MandrupPoulsen T, Dinarello CA, Nielsen JH \& Nerup J 1987 Interleukin 1 dose-dependently affects the biosynthesis of (pro)insulin in isolated rat islets of Langerhans. Diabetologia 30 474-480.

Stamler JS, Singel DJ \& Loscalzo J 1992 Biochemistry of nitric oxide and its redox-activated forms. Science 258 1898-1902.

Stewart CE \& Rotwein P 1996 Insulin-like growth factor-II is an autocrine survival factor for differentiating myoblasts. Journal of Biological Chemistry 271 11330-11338.

Suarez-Pinzon WL, Strynadka K, Schulz R \& Rabinovitch A 1994 Mechanisms of cytokine-induced destruction of rat insulinoma cells: the role of nitric oxide. Endocrinology 13 1006-1010.

Swenne I \& Hill DJ 1989 Growth hormone regulation of DNA replication, but not insulin production is mediated by somatomedin-C/insulin-like growth factor I in isolated pancreatic islets from adult rats. Diabetologia 32 191-197.

Thorens B 1992 Molecular and cellular physiology of GLUT-2, a high-Km facilitated diffusion glucose transporter. International Reviews in Cytology 137 209-238.

Van Schravendijk CF, Foriers A, Van Den Brande JL \& Pipeleers DG 1987 Evidence for the presence of type I insulin-like growth factor receptors on rat pancreatic A and B cells. Endocrinology 121 1784-1788. 
Van Schravendijk CFH, Heylen L, Van Den Brande JL \& Pipeleers DG 1990 Direct effect of insulin and insulin-like growth factor-I on the secretory activity of rat pancreatic beta cells. Diabetologia 33 649-653.

Welsh N, Bendtzen K \& Sandler S 1991 Influence of protease on inhibitory and stimulatory effects of interleukin 1 beta on beta-cell function. Diabetes 40 290-294.

Wijsman JH, Jonker RR, Keijzer R, Van de Velde CJ, Cornelisse CJ \& Van Dierendonck JH 1993 A new method to detect apoptosis in paraffin sections: in situ end labelling of fragmented DNA. Journal of Histochemistry and Cytochemistry 41 7-12.

Yamada K, Takane-Gyotuku N, Yuan X, Ichikawa F, Inada C \& Nonaka K 1996 Mouse islet cell lysis mediated by interleukin-1induced Fas. Diabetologia 39 1306-1312.

Received 9 July 1998

Accepted 4 November 1998 